\title{
Net nutrient flux in visceral tissues of goats fed diets based on maize or wheat ${ }^{*}$
}

\author{
Z.H. Sun ${ }^{1,2}$, Y. Hu ${ }^{1,4}$, S.M. Liu ${ }^{3}$, S.X. Tang1, X.F. Han', C.S. Zhou', \\ M. Wang ${ }^{1}$, Z.X. He ${ }^{1,2}$ and Z.L. Tan ${ }^{1,5}$
}

${ }^{1}$ Key Laboratory for Agro-ecological Processes in Subtropical Region, Institute of Subtropical Agriculture, CAS

Changsha 410125, P.R. China

${ }^{2}$ Chongqing Key Laboratory of Forage \& Herbivorce, Animal Science and Technology College,

Southwest University

Chongqing 400176, P.R. China

${ }^{3}$ The University of Western Australia, Faculty of Natural and Agricultural Sciences

Perth 60009, Australia

(Received 23 December 2009; revised version 19 January 2011; accepted 12 March 2011)

\begin{abstract}
The objective of this study was to investigate the effects of dietary starch sources on the net portaldrained viscera (PDV) flux of metabolites in goats fed diets based on maize and wheat, respectively. Eight 8-month-old Liuyang Black wether goats, with catheters surgically in the mesenteric vein, the portal vein and the carotid artery, were assigned to one of two diets for determination of net nutrient flux across the PDV. There were no differences $(\mathrm{P}>0.05)$ in plasma concentrations of glucose and ammonia-nitrogen $(\mathrm{N})$ in the portal vein and carotid artery, and net PDV flux of glucose and urea-N between maize diet and wheat diet. The portal plasma urea-N concentration and net PDV flux of ammonia-N of goats fed maize diet were lower $(\mathrm{P}<0.05)$ than those of goats fed wheat diet. Plasma concentrations in the portal vein and carotid artery and net PDV flux of certain essential amino acids of goats fed maize diet were higher $(\mathrm{P}<0.05)$ than those of goats fed wheat diet. The results of this study suggested that dietary starch source could affect $\mathrm{N}$ absorption and utilization in goats.
\end{abstract}

KEY WORDS: portal-drained viscera, starch sources, amino acid, urea-nitrogen, goat

\footnotetext{
* Supported by National Natural Science Foundation of China, No. 30600436, and Doctoral Found of Southwest University including The Program of Talent Introduction (SWU110054)

${ }^{4}$ This author contributed equally to this work as co-first author

${ }^{5}$ Corresponding author: e-mail: zltan@isa.ac.cn
} 


\section{INTRODUCTION}

The degradability and digestibility of dietary starch in the rumen influence not only the extent of microbial fermentation and protein synthesis in the rumen, but also the availability of nutrients in the postruminal digestive tract (Taniguchi et al., 1995). Complicated interrelationships between starch and protein affected ruminal fermentation products (Ørskov, 1975), microbial synthesis (Hoover and Stokes, 1991), whole-body nitrogen (N) metabolism, and milk yield and composition in ruminants (Khan et al., 2007). Tagari et al. (2004) reported that portal-drained viscera (PDV) net fluxes of total free amino acid, glycine, isoleucine, leucine, phenylalanine, proline, serine, threonine, tryptophan and valine were greater in cows fed steam-flaked maize than that of cows fed steam-rolled maize.

Maize and wheat are grains commonly used as feeds for ruminants. The total starch contents of wheat and maize were 77 and $70 \%$, respectively (Huntington, 1997). The starch from maize and wheat could be fermented in different manners in the rumen, the soluble starch (\% total starch) of maize and wheat was 24 and $60 \%$, and the potentially degradable starch (\% total starch) of maize and wheat was 6 and 33\% in the rumen, respectively (Offner et al., 2003). The soluble $\mathrm{N}$ $(\% \mathrm{CP})$ was 28 and $27 \%$, and the potentially degradable N (\% CP) was 65 and $71 \%$ for maize and wheat in the rumen, respectively (NRC, 2001). Obviously, the degradation characteristics of starch and $\mathrm{N}$ in the rumen differ for wheat and maize. The difference might result in variations in the ruminal microbial protein synthesis, which is mainly depended upon the fermentable energy and ruminal degradable protein (RDP), and availability of $\mathrm{N}$ and carbohydrate in the small intestine.

To examine this hypothesis, we have studied the rumen dynamic degradability of $\mathrm{CP}$ and starch of wheat and maize using in situ nylon bag technique, and found that the soluble N (\% CP) and soluble starch (\% total starch) were 34 and $74 \%$ for wheat, and 30 and 20\% for maize in the rumen, respectively (Wang and Tan, 2007). On the basis of the above-mentioned study, the present study was conducted to investigate the effects of starch source (wheat vs maize) on net flux of essential AA (EAA) across the portal-drained viscera and plasma concentrations of glucose, ammonia-N and urea-N in the portal vein and carotid artery of goats.

\section{MATERIAL AND METHODS}

\section{Animals and experimental design}

The use of animals and the procedure of the experiment with animals were followed in accordance to the Animal Care and Guidelines of Institute of 
Subtropical Agriculture, the Chinese Academy of Sciences.

Eight indigenous Liuyang Black male goats about 8 month-old with an initial liveweight (LW) of $20.0 \pm 0.5 \mathrm{~kg}$ were surgically fitted with permanent catheters in the mesenteric vein, portal vein and carotid artery. The surgical procedures were described by McLeod et al. (1997), and preparation of catheters and their maintenance during whole experiment were described by Huntington et al. (1989). The animals were held individually in stainless steel metabolic cages in a temperature-controlled $\left(21^{\circ} \mathrm{C}\right)$ and light-controlled $(16 \mathrm{~h}$ light and $8 \mathrm{~h}$ dark) animal house. Fresh water was available during whole experimental period.

The goats were randomly divided into two groups, and assigned to two diets. The two diets consisted of maize stover and a mixed concentrate (Table 1). The amounts of the feeds offered to goats were controlled to provide nutrition at a plane of approximately 1.3 times of metabolizable energy requirement for maintenance (Lu and Xie, 1991). Both the concentrate and maize stover were fed separately, and the daily supply of both the diets were divided into equal portions and fed at $2 \mathrm{~h}$ intervals throughout the entire experimental period in order to keep the balanced supply of fermentable energy and RDP to satisfy microbial protein synthesis in the rumen.

Table 1. Ingredients and nutrient composition of experimental diets, $\%$ DM basis ${ }^{1}$

\begin{tabular}{|c|c|c|}
\hline Item & Maize & Wheat \\
\hline \multicolumn{3}{|l|}{ Ingredients, \% } \\
\hline maize stover & 60 & 60 \\
\hline maize & 25 & - \\
\hline wheat & - & 25 \\
\hline rice bran & 1 & 3 \\
\hline soyabean meal & 10 & 11 \\
\hline fish meal & 2 & - \\
\hline $\mathrm{NaCl}$ & 1 & 1 \\
\hline Premix $^{2}$ & 1 & 1 \\
\hline \multicolumn{3}{|l|}{ Nutrient composition } \\
\hline $\mathrm{ME}, \mathrm{MJ} / \mathrm{kg}$ & 10.2 & 9.9 \\
\hline crude protein & 13.0 & 12.9 \\
\hline starch & 14.9 & 15.0 \\
\hline ruminal degradable protein & 5.40 & 5.72 \\
\hline neutral detergent fibre & 40.2 & 40.5 \\
\hline $\mathrm{Ca}$ & 0.65 & 0.68 \\
\hline $\mathrm{P}$ & 0.28 & 0.29 \\
\hline \multicolumn{3}{|c|}{${ }^{1}$ values, expressed on a DM basis, are the average of duplicates } \\
\hline \multicolumn{3}{|c|}{$\begin{array}{l}{ }^{2} \text { Premix contained per kg: g: } \mathrm{MgSO}_{4} \cdot \mathrm{H}_{2} \mathrm{O} 119, \mathrm{FeSO}_{4} \cdot 7 \mathrm{H}_{2} \mathrm{O} 2.5, \mathrm{CuSO}_{4} \cdot 5 \mathrm{H}_{2} \mathrm{O} 0.8, \mathrm{MnSO}_{4} \cdot \mathrm{H}_{2} \mathrm{O}_{3} \text {, } \\
\mathrm{ZnSO}_{4} \mathrm{H}_{2} \mathrm{O} \text { 5: mg: } \mathrm{Na}_{2} \mathrm{SeO}_{3} 10, \mathrm{KI} 40, \mathrm{CoCl}_{2} \cdot 6 \mathrm{H}_{2} \mathrm{O} \text { 30; IU: vit. A 95.000, vit. D 17.500, } \\
\text { vit. E } 18.000\end{array}$} \\
\hline \multicolumn{3}{|c|}{$\begin{array}{l}{ }^{3} \text { metabolizable energy values were as reported by Zhang and Zhang (1998), and the others were } \\
\text { determined values }\end{array}$} \\
\hline
\end{tabular}




\section{Samples and sampling procedures}

The experiment lasted for 12 days. Samples of feeds (the concentrate and maize stover) were taken daily, pooled, and sub-samples were taken. The feed refusals were collected daily, weighed, and pooled, and sub-samples were stored at $4^{\circ} \mathrm{C}$ for later analysis.

On day 12 , a priming dose $(15 \mathrm{ml})$ of p-aminohippuric acid (PAH, Serva GmbH, Heidelberg, Germany) solution $(15 \mathrm{mg} / \mathrm{ml})$ was given via the mesenteric vein at $07.30 \mathrm{~h}$, followed by a constant infusion of PAH solution at a rate of $12 \mathrm{mg} / \mathrm{min}$. Sixty min after the administration of the priming dose, $10 \mathrm{ml}$ blood samples for each goat, from the portal vein and carotid artery were collected at $08.30,11.30,14.30$ and $17.30 \mathrm{~h}$. Sodium heparin solution $(100 \mathrm{IU} / \mathrm{ml})$ was used as anticoagulant. The samples were cooled in ice and transferred to laboratory. The blood samples were centrifuged at $3,000 \mathrm{~g}$ at $4{ }^{\circ} \mathrm{C}$ for $20 \mathrm{~min}$. The plasma was then divided into five aliquots and stored at $-80^{\circ} \mathrm{C}$ for analyses of $\mathrm{PAH}$, urea-N, ammonia-N, glucose and AA concentrations.

\section{Chemical analysis}

Milled feed samples were analysed for DM (AOAC, 1990), Kjeldahl N (AOAC, 1990) and starch (Zinn, 1988). The NDF was determined using the methods described by Van Soest et al. (1991), with heat stable amylase and sodium sulphite processing in NDF procedure, and results are expressed with residual ash.

Plasma glucose concentration was determined by the glucose oxidase (Nangjing Jiancheng Co., Ltd., Jiangsu, China) method using a chemical autoanalyzer (AutoAnalyzer II, Technicon Industrial Systems, Tarrytown, NY). Urea-N in plasma was assayed by the diacetyl monoxime method (Marsh et al., 1965) via automated analysis (AutoAnalyzer II, Technicon Industrial Systems, Tarrytown, NY). Ammonia-N in plasma was estimated using glutamate dehydrogenase method (Da Fonseca-Wollheim and Heinze, 1992). For AA concentration in plasma, the plasma sample was first deproteinized in a sulphosalicylic acid solution $(60 \mathrm{~g} / 1$; containing $200 \mu \mathrm{mol} / \mathrm{l}$ nor-valine as an internal standard). Chromatographic separation of AA was performed on a Biotronik LC 5001 analyzer (Biotronik, Pusheim Bahnhof, Germany) according to the method of Moore and Stein (1954). Plasma PAH concentration was analysed according to the method of Eisemann et al. (1987).

\section{Calculation and statistical analysis}

Portal vein plasma flow (PVPF) was calculated by the equation (1) as follows:

$$
\mathrm{PVPF}=\mathrm{IR} /(\mathrm{PAHpv}-\mathrm{PAHa})
$$

where: IR - the infusion rate of PAH (mg/min), PAHpv and PAHa - PAH concentrations in plasma of the portal vein and carotid artery, respectively $(\mathrm{mg} / \mathrm{ml})$. 
Net PDV flux of nutrient was calculated according to the difference between portal and arterial plasma concentrations multiplied by corresponding PVPF:

$$
\text { PDV flux }=(\mathrm{Np}-\mathrm{Na}) \times \mathrm{PVPF}
$$

where: $\mathrm{Np}$ and $\mathrm{Na}$ - nutrient concentrations in the portal and arterial plasma, respectively.

There were four blood samples from each goat. The mean of four samples was calculated, and was used for the statistical analysis. To examine the difference between two diets, the t-test of two independent samples was performed. The P value of less than 0.05 was taken to declare statistical significance.

\section{RESULTS}

The average intakes (data not shown) of concentrate, maize stover, NDF, ADF, crude protein, starch and ruminal degradable protein (RDP) were 162, 242, 183, $115,52,60$ and $22 \mathrm{~g} / \mathrm{d}$ in maize group, and 164, 243, 184, 116, 52, 61 and $24 \mathrm{~g} / \mathrm{d}$ in wheat group, respectively. The daily DM, NDF, ADF, CP and starch intakes of both groups were not affected by treatment $(\mathrm{P}>0.05)$, but the RDP intake of goats in wheat group was higher $(\mathrm{P}<0.05)$ than that of goats in maize group.

Plasma concentrations of glucose, urea- $\mathrm{N}$ and ammonia-N are shown in Table 2. There were no differences $(\mathrm{P}>0.05)$ in glucose and ammonia- $\mathrm{N}$ concentrations in the portal vein and carotid artery, and net PDV fluxes of glucose and urea-N between the two diets. However, urea-N concentration in the portal vein and net PDV flux of ammonia-N for goats fed maize diet were lower than for goats fed wheat diet $(\mathrm{P}<0.05)$.

Table 2. Plasma metabolite concentrations of goats fed either a maize or wheat diet

\begin{tabular}{lcccc}
\hline Item & Maize & Wheat & SEM $^{1}$ & $\mathrm{P}^{2}$ \\
\hline Portal vein plasma flow, ml/min & 662 & 670 & 10 & $\mathrm{NS}$ \\
$\begin{array}{l}\text { Glucose } \\
\quad \text { carotid artery mmol/1 }\end{array}$ & 3.59 & 3.47 & 0.06 & $\mathrm{NS}$ \\
$\quad$ portal vein, $\mathrm{mmol} / \mathrm{l}$ & 3.41 & 3.32 & 0.26 & $\mathrm{NS}$ \\
PDV flow, $\mu \mathrm{mol} / \mathrm{min}$ & -123 & -98.7 & 49.3 & $\mathrm{NS}$ \\
Ammonia- $N$ & & & & \\
$\quad$ carotid artery, $\mu \mathrm{mol} / 1$ & 76.2 & 77.0 & 0.96 & $\mathrm{NS}$ \\
portal vein, $\mu \mathrm{mol} / \mathrm{l}$ & 93.8 & 97.2 & 1.4 & $\mathrm{NS}$ \\
PDV flow, $\mu \mathrm{mol} / \mathrm{min}$ & 11.7 & 13.5 & 0.52 & $*$ \\
Urea- $N$ & & & & \\
$\quad$ carotid artery, $\mathrm{mmol} / \mathrm{l}$ & & & & \\
portal vein, $\mathrm{mmol} / \mathrm{l}$ & 5.05 & 5.21 & 0.14 & $\mathrm{NS}$ \\
PDV flux, $\mu \mathrm{mol} / \mathrm{min}$ & 4.82 & 5.15 & 0.08 & $*$ \\
\hline
\end{tabular}

${ }^{1}$ SEM - the pooled standard error of means; ${ }^{2} \mathrm{NS}$ - not significant; *, $\mathrm{P}<0.05$ 
Essential AA concentrations in plasma are given in Table 3. The concentrations of lysine (Lys), methionine (Met), histidine (His) and EAA of goats fed maize diet in the carotid or portal vein were higher than those of goats fed wheat diet $(\mathrm{P}<0.05)$. The concentration of Thr in the carotid for goats fed maize diet was higher than for goats fed wheat diet $(\mathrm{P}<0.05)$.

Table 3. Plasma essential amino acids (EAA) concentrations in the carotid artery and portal vein of goats fed either a maize or wheat diet, $\mu \mathrm{g} / \mathrm{ml}$

\begin{tabular}{|c|c|c|c|c|c|c|c|c|}
\hline \multirow{2}{*}{$\begin{array}{l}\text { Amino } \\
\text { acids }\end{array}$} & \multicolumn{2}{|c|}{ Carotid artery } & \multirow{2}{*}{ SEM $^{1}$} & \multirow{2}{*}{$\mathrm{P}$} & \multicolumn{2}{|c|}{ Portal vein } & \multirow{2}{*}{ SEM $^{1}$} & \multirow{2}{*}{$\mathrm{P}^{2}$} \\
\hline & maize & wheat & & & maize & wheat & & \\
\hline Lys & 16.4 & 13.1 & 0.56 & ** & 19.3 & 15.3 & 0.50 & $* *$ \\
\hline Met & 3.27 & 1.92 & 0.11 & $* * *$ & 3.61 & 2.13 & 0.12 & $* * *$ \\
\hline Thr & 16.6 & 15.0 & 0.42 & $*$ & 18.1 & 16.6 & 0.46 & NS \\
\hline Arg & 13.9 & 14.0 & 0.56 & NS & 16.1 & 15.9 & 0.51 & NS \\
\hline His & 3.57 & 2.14 & 0.08 & $* * *$ & 5.78 & 4.42 & 0.13 & $* * *$ \\
\hline Leu & 16.1 & 15.9 & 0.55 & NS & 18.5 & 17.6 & 0.60 & NS \\
\hline Ile & 9.04 & 8.60 & 0.35 & NS & 10.7 & 10.3 & 0.32 & NS \\
\hline Val & 25.0 & 24.6 & 0.58 & NS & 28.5 & 27.5 & 0.57 & NS \\
\hline Phe & 3.67 & 3.79 & 0.18 & NS & 4.53 & 4.62 & 0.18 & NS \\
\hline EAA & 107 & 98.9 & 2.44 & $*$ & 128 & 115 & 2.12 & * \\
\hline
\end{tabular}

${ }^{1}$ SEM - the pooled standard error of means; ${ }^{2} \mathrm{NS}$ - not significant; * $\mathrm{P}<0.05 ; * * \mathrm{P}<0.01 ; * * * \mathrm{P}<0.001$

Net PDV flux of plasma EAA is listed in Table 4. Net PDV fluxes of Lys, Met and Val of goats fed maize diet were higher than those of goats fed wheat diet $(\mathrm{P}<0.05)$.

Table 4. Plasma EAA PDV net flux of goats fed either a maize or wheat diet, $\mathrm{mg} / \mathrm{min}$

\begin{tabular}{|c|c|c|c|c|}
\hline \multirow[b]{2}{*}{ Amino acid } & \multicolumn{2}{|c|}{ Diets } & \multirow[b]{2}{*}{ SEM $^{1}$} & \multirow{2}{*}{$\mathrm{P}^{2}$} \\
\hline & maize & wheat & & \\
\hline Lys & 1.96 & 1.48 & 0.10 & * \\
\hline Met & 0.23 & 0.15 & 0.03 & $* *$ \\
\hline Thr & 1.02 & 1.13 & 0.14 & NS \\
\hline Arg & 1.42 & 1.31 & 0.06 & NS \\
\hline His & 1.46 & 1.53 & 0.07 & NS \\
\hline Leu & 1.61 & 1.22 & 0.28 & NS \\
\hline Ile & 1.12 & 1.16 & 0.06 & NS \\
\hline Val & 2.25 & 1.94 & 0.14 & * \\
\hline Phe & 0.57 & 0.56 & 0.03 & NS \\
\hline EAA & 11.6 & 10.5 & 0.39 & NS \\
\hline
\end{tabular}

${ }^{1} \mathrm{SEM}$ - the pooled standard error of means; ${ }^{2} \mathrm{NS}$ - not significant; ${ }^{*} \mathrm{P}<0.05 ; * * \mathrm{P}<0.01$

\section{DISCUSSION}

Glucose. In the present study, no differences in plasma glucose concentration and net PDV flux of glucose between maize and wheat diets indicated that different starch sources (at least from maize and wheat) had no effects on glucose 
net PDV absorption and metabolism. Our results were consistent with previous reports. Across a wide range of experiments encompassing varied diets, intakes and physiological states, net glucose absorption was almost always not changed, valued at zero or negative (Reynolds, 2006). The site of starch being digested had an impact on glucose supply at small intestine, however, it appeared that increases in glucose supply at the small intestine were accompanied by increased utilization of arterial glucose in tissues drained by the portal vein, such as mesenteric and omental fat depots (Reynolds, 2006). Circulating glucose in ruminants was mostly derived from gluconeogenesis which depended on glucogenic precursors mainly including propionate and glucogenic AA (Yong, 1977).

Ammonia- $N$. In the present study, the net PDV ammonia-N flux of goats in wheat diet was higher than that of goats in maize diet. Nozière et al. (2005) reported that portal net appearance of ammonia tended to decrease from 108 to $73 \mathrm{mmol} / \mathrm{h}$ when steers were fed the diets based on wet and ground maize, and the diets based on dry and cracked maize, respectively. The results of present study and previous reports indicated that net PDV flux of ammonia-N might be affected by starch source and the processing of grain. Net PDV flux of ammonia-N was positively related to the ruminal ammonia-N concentration (Nozière et al., 2005). Therefore, the difference in net PDV flux of ammonia- $\mathrm{N}$ in goats between maize and wheat diets suggested there was difference in the ruminal ammonia- $\mathrm{N}$ concentration in goats fed maize and wheat diets. Ammonia-N concentration in the rumen can vary greatly depending on diet, time of feeding and feeding frequency, animal and other factors. Hristov et al. (2005) pointed out that ammonia-N concentration in the rumen was related to the release rate of $\mathrm{N}$ and carbohydrate, and ruminal fluid passage. According to our previous study (Wang and Tan, 2007), we found that the difference in soluble starch in the rumen between maize and wheat diets was much higher than the difference in soluble $\mathrm{N}$ for goats. On the other hand, daily RDP intake of per goat in maize group was lower than that in wheat group; furthermore, feeds were equally given every $2 \mathrm{~h}$ in the current study. Under this feeding regime, the difference in net PDV ammonia-N flux between maize and wheat diets might be probably ascribed to the differences in the release rate of starch and intake of RDP.

Urea-N. Plasma urea-N concentration is a useful index for the evaluation of $\mathrm{N}$ utilization by animal body (Sun et al., 2007). The results of present study suggested that dietary starch source (at least from maize or wheat) could affect $\mathrm{N}$ utilization by goats. It has been approved that plasma urea-N concentration of ruminant could be affected by dietary carbohydrate source (Osborne et al., 2002). The reasons for the current result might be related to higher net PDV flux of ammonia-N of goats fed wheat diet, which was turned into urea-N in the liver. In addition, certain higher plasma EAA concentration or EAA PDV net flux (such as Lys, Met, Thr and His) of goats fed maize diet might be due to other reasons. 
It would be needed to do more exact experiments so as to obtain the reasonable explanation.

Amino acids. The current results indicated that the total amount of absorbed EAA from gastrointestinal tract (GIT) between wheat and maize diets did not differ, but the net fluxes of Lys, Met and Val differed. The quantity of net PDV flux of EAA reflected the quantity of absorbable EAA from the GIT. The microbial protein entering the duodenum is a dominant factor of determining EAA flow at the duodenum of dairy cows (Boguhn et al., 2006; Lapierre et al., 2006). Therefore, the reason for the difference in absorbed Lys, Met and Val from GIT between maize and wheat diets might mainly reflect the difference in the microbial protein entering the duodenum. Fermentable energy and RDP are essential for microbial protein synthesis in the rumen. Energy availability, or lack of synchrony between fermentable energy and RDP, could limit the utilization of available $\mathrm{N}$ by the ruminal microorganisms (Hristov et al., 2005). In the present study, the difference in RDP between maize and wheat diets was far less than the difference in starch degradation in the rumen, the release of carbohydrate was therefore likely to be more synchronous to RDP in maize diet compared with wheat diet, and the difference in synchronization of fermentable carbohydrate and RDP between wheat and maize diets might further result in the difference in the yield of ruminal microbial protein and influence the net PDV flux of AA. Tagari et al. (2004) also reported the difference in starch degradation rate of diet in the rumen of cows caused by different processing technique for maize had significant effects on the net PDV flux of free and peptide bound AAs, especially EAA of free AAs.

\section{CONCLUSIONS}

This study demonstrated that carbohydrate of maize was associated with higher, when compared with wheat, net fluxes of lysine, methionine and valine across portal-drained viscera (PDV) in goats, and associated with lower urea-N concentration in the portal vein and net PDV flux of ammonia-N. The results suggested that synchronization between fermentable carbohydrate and in the rumen ruminal degradable protein was advantageous to microbial protein synthesis and utilization of dietary nitrogen by goats.

\section{REFERENCES}

AOAC, 1990. Association of Official Analytical Chemists, Official Methods of Analysis. 15 $5^{\text {th }}$ Edition. Washington, DC

Boguhn J., Kluth H., Rodehutscord M., 2006. Effect of total mixed ration composition on amino acid profiles of different fractions of ruminal microbes in vitro. J. Dairy Sci. 89, 1592-1603 
Da Fonseca-Wollheim F., Heinze K.G., 1992. Which is the appropriate coenzyme for measurement of ammonia with glutamate dehydrogenase? Eur. J. Clin. Chem. Clin. Biochem. 30, 537-540

Eisemann J.H., Huntington G.B., Ferrell C.L., 1987. Blood flow to hindquarters of steers measured by transit ultrasound and indicator dilution. J. Dairy Sci. 70, 1385-1390

Hoover W.H., Stokes S.R., 1991. Balancing carbohydrates and protein for optimum rumen microbial yield. J. Dairy Sci. 74, 3630-3644

Hristov A.N., Ropp J.K., Grandeen K.L., Abedi S., Etter R.P., Melgar A., Foley A.E., 2005. Effect of carbohydrate source on ammonia utilization in lactating dairy cows. J. Anim. Sci. 83, 408-421

Huntington G.B., 1997. Starch utilization by ruminants: From basics to the bunk. J. Anim. Sci. 75, $852-867$

Huntington G.B., Reynolds C.K., Stroud B.H., 1989. Techniques for measuring blood flow in splanchnic tissues of cattle. J. Dairy Sci. 72, 1583-1595

Khan M.A., Lee H.J., Lee W.S., Kim H.S., Kim S.B., Ki K.S., Park S.J., Ha J.K., Choi Y.J., 2007. Starch source evaluation in calf starter: I. Feed consumption, body weight gain, structural growth, and blood metabolites in Holstein calves. J. Dairy Sci. 90, 5259-5268

Lapierre H., Pacheco D., Berthiaume R., Ouellet D.R., Schwab C.G., Dubreuil P., Holtrop G., Lobley G.E., 2006. What is the true supply of amino acids for a dairy cow? J. Dairy Sci. 89, E1-E14

Lu D.X., Xie C.W., 1991. Modern Method and Technology on Ruminant Nutrition Research. Chinese Agriculture Press, Beijing (China)

Marsh W.H., Fingerhut B., Miller H., 1965. Automated and manual direct methods for the determination of blood urea. Clin. Chem. 11, 624-627

McLeod K.R., Bauer M.L., Harmon D.L., Reynolds C.K., Mitchell Jr G.E., 1997. Effects of exogenous somatostatin and cysteamine on net nutrient flux across the portal-drained viscera and liver of sheep during intraduodenal infusion of starch hydrolysate and casein. J. Anim. Sci. 75, 3026-3037

Moore S., Stein W.H., 1954. Procedures for the chromatographic determination of amino acids on four per cent cross-linked sulfonated polystyrene resins. J. Biol. Chem. 211, 893-906

NRC, 2001. Nutrient Requirements of Dairy Cattle. National Academy Press. $17^{\text {th }}$ revised Edition. Washington, DC

Nozière P., Rèmond D., Lemosquet S., Chauveau B., Durand D., Poncet C., 2005. Effect of site of starch digestion on portal nutrient net fluxes in steers. Brit. J. Nutr. 94, 182-191

Offner A., Bach A., Sauvant D., 2003. Quantitative review of in situ starch degradation in the rumen. Anim. Feed Sci. Tech. 106, 81-93

Osborne V.R., Leslie K.E., McBride B.W., 2002. Effect of supplementing glucose in drinking water on the energy and nitrogen status of the transition dairy cows. Can. J. Anim. Sci. 82, 427-433

Ørskov E.R., 1975. Manipulating of rumen fermentation for maximum food utilization. World Rev. Nutr. Diet. 22, 152-182

Reynolds C.K., 2006. Production and metabolic effects of site of starch digestion in dairy cattle. Anim. Feed Sci. Tech. 130, 78-94

Reynolds C.K., Harmon D.L., Cecava M.J., 1994. Absorption and delivery of nutrients for milk protein synthesis by portaldrained viscera. J. Dairy Sci. 77, 2787-2808

Sun Z.H., Tan Z.L., Liu S.M. et al., 2007. Effects of dietary methionine and lysine sources on nutrient digestion, nitrogen utilization, and duodenal amino acid flow in growing goats. J. Anim. Sci. 85, 3340-3347

Tagari H., Webb Jr. K., Theurer B. et al., 2004. Portal drained visceral flux, hepatic metabolism, and mammary uptake of free and peptide-bound amino acids and milk amino acid output in dairy cows fed diets containing corn grain steam flaked at 360 or steam rolled at $490 \mathrm{~g} / \mathrm{L}$. J. Dairy Sci. $87,413-430$ 
Taniguchi K., Huntington G.B., Glenn B.P., 1995. Net nutrient flux by visceral tissues of beef steers given abomasal and ruminal infusions of casein and starch. J. Anim. Sci. 73, 236-249

Van Soest P.J., Robertson J.B., Lewis B.A., 1991. Symposium: carbohydrate methodology, metabolism and nutritional implications in dairy cattle. Methods for dietary fiber, neutral detergent fiber, and nonstarch polysaccharides in relation to animal nutrition. J. Dairy Sci. 74, 3583-3597

Wang S.P., Tan Z.L., 2007. Effects of starch sources on digestion, metabolism, meat quality and antioxidant capacity of goat. PhD. Thesis, Institute of Subtropical Agriculture, CAS, Hunan (China)

Young J.W., 1977. Gluconeogenesis in cattle: significance and methodology. J. Dairy Sci. 60, 1-15

Zinn R.A., 1988. Comparative feeding value of supplemental fat in finishing diets for feedlot steers supplemented with and without monensin. J. Anim. Sci. 66, 213-227 